\title{
Green Tea Intake and Exercise Reduce Some Biochemical Markers of Obese Adolescents
}

Jae K. Yang', Ji Y. Jung ${ }^{1}$, Seol J. Kang ${ }^{2}$, Gang W. Cheong ${ }^{3}$, Jong C. Kim ${ }^{4}$, Seong K. Ko ${ }^{5}$

and So B. Jeong ${ }^{2}$ *

${ }^{1}$ Division of Environmental Forest Science, Gyeongsang National University, Institute of Agriculture \& Life Sciences, Jinju 660-701, Korea

${ }^{2}$ Department of Physical Education, Gyeongsang National University, Jinju 660-701, Korea

${ }^{3}$ Division of Applied Life Sciences, Gyeongsang National University, Jinju 660-701, Korea

${ }^{4}$ Institute of Hadong Green Tea, Hadong-gun, Gyeongnam 667-804, Korea

${ }^{5}$ Department of Physical Education, Daegu University, Daegu 712-714, Korea.

Received January 31, 2011 /Accepted February 11, 2011

\begin{abstract}
The effects of green tea consumption and/or exercise for 12 weeks on body weight and select biochemical markers in plasma were evaluated in obese adolescents with a fat ratio of greater than $25 \%$. The subjects were randomly divided into a control group $(n=9)$, green tea consumption group $(n=9)$, exercise group $(n=9)$ and green tea consumption with exercise group $(n=9)$. Subjects in both green tea consumption group and green tea consumption with exercise group were given more than five cups of green tea extract in hot water $\left(90^{\circ} \mathrm{C}\right)$ daily, equivalent to $1.5-1.7 \mathrm{~g}$ dry green tea, for 12 weeks. Subjects in both the exercise group and green tea consumption with exercise group participated in a training program (HRmax 60-70\%, $60 \mathrm{~min}$ /day) for 12 weeks. Control subjects were only given water equal to the quantity of green tea being given to the subjects of green tea consumption. No significant changes body weights were seen in any of these treatments, but the waist to hip ratio was reduced with treatments of both green tea and exercise. The control group showed no significant changes in TNF- $\alpha$, IL- 6 and leptin levels. Green tea consumption reduced leptin $(p<0.05)$, TNF- $\alpha$, and leptin levels. Exercise lowered TNF- $\alpha(p<0.05)$, IL-6 $(p<0.01)$, and leptin $(p<0.05)$ concentrations. Meanwhile, a combination of green tea consumption and exercise lowered TNF- $\alpha$, IL-6 $(p<0.05)$ and leptin $(p<0.05)$ levels. These results indicate that green tea consumption and exercise both had a positive effect on the reduction of inflammatory cytokines, TNF- $\alpha$, IL- 6 and leptin, in obese adolescents, but no synergistic effect on the reduction of these cytokines.
\end{abstract}

Key words : Obese adolescent, exercise, green tea, inflammatory cytokines

\section{서 론}

청소년기는 성장과 발달이 빠르고 지방조직이 증가하기 때문에 비만발생에 위험한 시기이고, 성인비만으로 진전되 기 때문에 청소년의 철저한 비만관리가 절실히 요구된다. 특히 청소년 비만은 심혈관 질환과 밀접한 관계가 있는 고 혈압, 제2형당뇨병 및 고지혈증 등을 조기에 유발시키는 문 제점을 안고 있다[13,18]. 지방세포에서 분비되는 tumor necrosis factor- $\alpha$ (TNF- $\alpha$ ), interleukin-6 (IL-6), leptin 등의 면 역조절 adipocytokine은 지방대사, 항상성 에너지의 균형 및 인슐린 저항성을 조절하는 등 여러 가지 생리학적 효과를 갖는다[1,3,11,20]. 하지만 이들 adipocytikine 분비 이상은 비만과 관련된 대사성 증후군과 심혈관 질환의 발병을 촉진 하는 것으로 보고되었다[1].

청소년비만은 유산소운동이나 녹차와 같은 기능성 식품을

*Corresponding author

Tel : +82-55-751-5710, Fax : +82-55-751-5700

E-mail : sbjeong@gnu.kr
섭취하여 에너지소비와 지방산산화를 증가 시킴으로써 해결할 수 있다. 운동은 에너지 소비를 요구하기 때문에 체중조절에 필수적인 요인이 된다. 특히 유산소운동은 죽상경화를 유발시 키는 triglyceride (TG)과 low density lipoproteincholestrerol (LDL-C) 등은 감소시키는 반면 항 동맥경화 작용을 하는 high density lipoproteincholestrerol (HDL-C)은 증가시키는 것으 로 보고되었다[14,15]. 또한 유산소운동은 TNF-a, IL-6 등의 cytokine 생성에 긍정적인 영향을 미친다[16,21].

녹차는 열 발생과 지방산화를 증가시켜 체지방함량을 감 소 시킴과 동시에, 다양한 약리효과를 나타내는 것으로 보고 되었다[2,5,6]. 녹차는 소비가 많고 여러 가지 생리활성이 과 학적으로 규명되고 있어 기능성 식품으로서의 가치가 재평 가 되고 있다[7,8,17]. 특히, 녹차에 함유되어 있는 epigallocatechin gallate (EGCG)는 지방산 산화력의 증가 및 체 지방, 복부지방을 감소시키며 $[13,18,27]$, 카페인 및 methylxanthine은 지방산산화 촉진 또는 지방합성을 억제하기 때문 에 비만예방 및 치료에 활용되고 있다. 이들 성분은 체지방 의 분해를 저해하는 adenosine 작용을 억제하여 체지방분해 
를 촉진하고 에너지 소비량을 증가시키는 효과가 있다[19]. 또한 EGCG는 체지방 감소와 관련성이 있는 TNF-a와 같은 cytokine 생성을 효율적으로 억제하는 물질로 밝혀졌다[4,24] 그리고 많은 녹차에 관련된 연구에서 녹차가 비만이나 심혈 관계질환에 매우 도움이 된다고 보고하였으나 그렇지 않은 경우도 있는데, 이러한 결과는 녹차섭취방법이나 연구 대상 자 개인차에 기인한다[2].

지금까지 비만에 대한 녹차섭취 효과연구는 주로 여고생이 나 성인을 대상으로 수행되었나 성장과 발육이 왕성한 시기에 있는 청소년인 중학생을 대상으로 연구한 경우는 전무한 실정 이다. 본 연구에서는 녹차섭취나 운동이 비만 청소년 학생의 체지방조절에 미치는 영향과 몇 가지 biochemical marker에 관하여 연구하였다.

\section{재료 및 방법}

\section{실험대상자}

본 연구의 실험대상자는 J시에 소재하고 있는 J중학교 재학 생 중 체지방율(\% fat)이 $25 \%$ 이상인 비만 남학생으로 대조군 9명 $(25.2 \pm 7.0 \%)$, 녹차섭취군 9 명 $(30.4 \pm 4.7 \%)$, 운동군 9 명 $(27.5 \pm 3.8 \%)$, 녹차섭취와 운동군 9명 $(35.1 \pm 3.5 \%)$ 총 36명이었 다. 대상자는 실험 3 개월 전까지 규칙적인 운동을 실시하지 않았으며, 임상적으로 특정한 질환을 진단 받지 않았다. 또한 이들은 연구목적과 내용 및 절차에 대하여 충분한 설명과 잠 재적인 위험 요소를 숙지 받은 후 자발적으로 참여 의사를 밝히고 동의하였다.

\section{녹차섭취}

2009년 4 6월에 $\mathrm{H}$ 지역에서 생산된 우수한 품질의 녹차를 구입하여 사용하였다. 대상자의 녹차섭취는 전문가의 조언을 받아 건물중량 기준으로 1 일 1.5-1.7 g이었다. 녹차는 관행의 방법으로 열수 추출하여 혈중에 일정한 카테킨 함량을 유지하 기 위하여 식후 한 잔 그리고 식간에 한 잔씩, 매일 6 8 잔을 12 주 동안 음용하였다. 대조군 연구대상자는 음료수를 녹차추 출물 섭취량만큼 섭취하였다.

\section{운동프로그램}

운동프로그램은 준비운동(맨손체조 및 스트레칭) 5 분, 트레 드밀에서 걷기운동 50 분 및 정리운동(맨손체조 및 스트레칭) 5 분 총 60 분으로 구성되었다. 운동은 총 12 주간 실시하였고, 운동빈도는 주 5 회, 오후 4 시부터 오후 6 시 30 분 사이에 실시 하였다. 주요 운동인 트레드밀에서의 걷기운동 강도는 60 $70 \% \mathrm{HRmax}$ 로 설정하였으며, 연구 대상자의 안정 시 심박수 를 측정한 후, Kavornen의 식[9]에 의거하여 목표 심박수[목표 심박수 $=($ 최대 심박수-안정 시 심박수 $) \times($ 운동 강도+안정 시 심 박수), 최대 심박수 $=220 \times$ 나이]를 계산하였다. 운동실시 5 분간
은 트레드밀에서 적응하기 위해 천천히 걷기를 실시한 후 속 도를 높여 목표 심박수에 도달하도록 하였다. 운동 시작 후 40 분이 지나면 걷기 속도를 줄여 심박수를 안정상태로 되돌리 도록 하였으며 운동 중 목표 심박수 확인은 무선심박 수 측정 기(Polar accurex plus, Polar Electro OY, Filamd)를 착용하여 연구 대상자들의 목표 심박수 범위를 확인하였다.

\section{식생활 관리}

연구기간 중 연구대상자들은 일상적인 식생활 이외에 약물 복용이나 반복적인 카페인 음료와 유사한 식품섭취를 제한하 였다. 또한 연구 대상자의 식생활 행위를 주 4-5회 조사하여 연구 결과에 영향을 미칠 수 있는 행위를 수정하도록 하였으 며 수정이 어려운 경우 연구 대상에서 제외하였다.

\section{채혈 및 혈액 분석}

채혈은 간단한 문진을 통하여 실험 목적에 부합되는 조 건이 형성된다고 판단되면, 실험 실시 전과 실험이 끝나는 12 주 후 동일방법으로 2회 실시 하였다. 혈액검사는 8-10시 간의 공복상태 후 오전 9시 전 후로 전완 동맥에서 헤파린 으로 처리된 혈액 채취 튜브에 혈액 $10 \mathrm{ml}$ 채취하였다. 채 혈된 혈액은 원심분리기를 이용하여 $4,000 \mathrm{rpm}$ 으로 10 분간 원심 분리한 후 serum과 plasma로 분리하고 plasma는 냉 동 보관하면서 assay kit (Sigma-Aldrich, St. Louis, MO)를 이용하여 TNF-a, IL-6, leptin, TG 및 HDL-C 함량을 측정하 였다.

\section{통계처리}

SPSS Ver. 17.0을 이용하여 사전값을 공변인(covariate)으로 한 공분산분석(ANCOVA)을 실시하였으며, 차이가 있는 경우 추정된 주변평균(estimated marginal means; $\mathrm{EMM}$ )에 대해서 는 multiple comparison analysis 중 Bonferroni 법으로 검증하 였다. 유의수준은 $p<0.05$ 이하로 하였다.

\section{결과 및 고찰}

비만의 실질적인 원인은 체지방산화억제 작용과 에너지소 비 감소에 기인하는 것이기 때문에 비만치료는 지방산화를 촉진하고 에너지소비를 촉진시킬 수 있는 방법을 강구하는 것이다. 다양한 기능성 식품이나 물질이 지방산산화를 촉진하 는 역할을 하는 것으로 밝혀졌다[5,17,23]. 특히, 녹차에는 카테 킨, 카페인 및 methylxanthine 등과 같은 화합물을 함유하고 있어 에너지소비를 증가시키고 체지방산화를 촉진하는 효과 가 있는 것으로 알려져 있으며, 더욱이 녹차의 polyphenol은 콜레스테롤 흡수를 억제하여 콜레스테롤을 담즙산 형태로의 배설을 촉진시켜 심혈관질환 위험을 감소하는 효과도 있다 $[6,19,23]$. 또한 운동은 에너지소비를 증가시킬 수 있는 가장 
효율적인 방법이다. 따라서 본 연구에서는 녹차와 운동의 단 독 효과와 상승효과를 중학교 비만남학생들을 대상으로 12 주 간 처리하여 연구하였다.

먼저 녹차섭취, 운동 및 이들의 병행이 체중에 미치는 영향 을 조사하였다(Table 1). 녹차섭취나, 운동 및 이들의 병행은 체중변화에 아무런 영향을 미치지 못하였다. 또한 실험 전 체 중 값을 공변인으로 조정하여 실험 후 체중을 처리 별 ANCOVA 결과, 처리간 체중에도 아무런 차이가 없었다 (Table 2), 이와 같은 결과는 아마도 12 주간의 처리기간이 짧 고, 연구대상자(중학생 비만 남학생)의 대사가 활발한 젊은 중 학생이기 때문인 것으로 생각된다. 체중의 변화는 없었으나 대상자의 특성 상 의자에 앉아 있는 시간이 많은 관계로 대상 자의 복부지방률 변화를 측정하였다(Table 3). 녹차섭취와 운 동 단독처리는 대상자의 복부지방률에는 아무런 영향을 미치 지 않았으나 이들의 병행처리는 복부지방률을 유의성 있게

Table 1. Effect of green tea and exercise treatments on the body weight of subjects for 12 weeks

\begin{tabular}{lccc}
\hline \multirow{2}{*}{ Treatment $^{1)}$} & \multicolumn{2}{c}{ Body weight $(\mathrm{kg} /$ person) } & Paired \\
\cline { 2 - 3 } & $\begin{array}{c}\text { Prior to } \\
\text { treatment }\end{array}$ & $\begin{array}{c}\text { Post } \\
\text { treatment }\end{array}$ & $\begin{array}{c}\text { t-test } \\
\text { Control }\end{array}$ \\
Green Tea & $71.37 \pm 10.23^{2)}$ & $70.70 \pm 10.41$ & 1.05 \\
Exercise & $74.59 \pm 5.84$ & $72.61 \pm 5.89$ & 1.73 \\
Green Tea \& Exercise & $74.32 \pm 5.48$ & $74.07 \pm 6.37$ & 0.17 \\
\hline
\end{tabular}

${ }^{1)}$ Green tea extract (1.5-1.7 g dry weight $/ 120 \mathrm{ml}$ tap water, $\left.90^{\circ} \mathrm{C}\right)$ was daily given to a subject for 12 weeks. Strength and duration of exercise were shown in Materials and Methods.

${ }^{2)} \mathrm{Mean} \pm \mathrm{SD}$ of 9 individuals.
감소하였다 $(p<0.05)$. 그러나 사전 복부지방률을 공변인으로 설정하여 처리간 ANCOVA 결과 차이는 나타나지 않았다

Table 3. Effect of green tea and exercise treatments on waist/hip ratio of subjects for 12 weeks

\begin{tabular}{lccc}
\hline \multirow{2}{*}{ Treatment $^{1)}$} & \multicolumn{2}{c}{ waist/hip ratio } & Paired \\
\cline { 2 - 3 } & $\begin{array}{c}\text { Prior to } \\
\text { treatment }\end{array}$ & $\begin{array}{c}\text { Post } \\
\text { treatment }\end{array}$ & t-test \\
\hline Control & $0.86 \pm 0.06^{2)}$ & $0.86 \pm 0.07$ & -0.26 \\
Green Tea & $0.90 \pm 0.05$ & $0.89 \pm 0.04$ & 0.98 \\
Exercise & $0.87 \pm 0.04$ & $0.86 \pm 0.04$ & 0.25 \\
Green Tea \& Exercise & $0.94 \pm 0.05$ & $0.92 \pm 0.06$ & $2.34^{*}$ \\
\hline
\end{tabular}

${ }^{1)}$ Green tea extract (1.5-1.7 g dry weight/120 ml tap water, $90^{\circ} \mathrm{C}$ ) was daily given to a subject for 12 weeks. Strength and duration of exercise were shown in Materials and Methods.

${ }^{2)} \mathrm{Mean} \pm \mathrm{SD}$ of 9 individuals. ${ }^{*} \times 0.05$.

Table 4. Change in TNF- $a$ concentration in bloods from subjects treated with green tea extract and exercise for 12 weeks of treatments

\begin{tabular}{lccc}
\hline \multirow{2}{*}{ Group $^{1)}$} & \multicolumn{2}{c}{ TNF- $\alpha(\mathrm{pg} / \mathrm{dl})$} & Paired \\
\cline { 2 - 3 } & $\begin{array}{c}\text { Prior to } \\
\text { treatment }\end{array}$ & $\begin{array}{c}\text { Post } \\
\text { treatment }\end{array}$ & t-test \\
\hline Control & $8.51 \pm 2.96^{2)}$ & $5.65 \pm 3.74$ & 2.17 \\
Green Tea & $3.42 \pm 1.18$ & $2.68 \pm 1.31$ & 2.07 \\
Exercise & $4.77 \pm 1.95$ & $3.05 \pm 1.58$ & $2.43^{*}$ \\
Green Tea \& Exercise & $5.53 \pm 1.73$ & $4.62 \pm 3.02$ & 1.06 \\
\hline
\end{tabular}

${ }^{1)}$ Green tea extract $\left(1.5-1.7 \mathrm{~g}\right.$ dry weight $/ 120 \mathrm{ml}$ tap water, $\left.90^{\circ} \mathrm{C}\right)$ was daily given to a subject for 12 weeks. Strength and duration of exercise were shown in Materials and Methods.

${ }^{2)}$ Mean \pm SD of 9 individuals. ${ }^{*} p<0.05$.

Table 2. ANCOVA for biomarkers in bloods from subjects treated with green tea extract and exercise for 12 weeks

\begin{tabular}{llrrrrr}
\hline Parameter & Source & \multicolumn{1}{c}{$\mathrm{SS}^{1)}$} & $\mathrm{df}^{2}$ & $\mathrm{MS}^{3)}$ & $\mathrm{F}^{4)}$ & $\mathrm{p}^{5}$ \\
\hline \multirow{2}{*}{ Body weight } & Contrast & 16.56 & 3 & 5.52 & 0.56 & 0.65 \\
& Error & 305.87 & 31 & 9.87 & & \\
Waist/hip ratio & Contrast & 0.02 & 3 & 0.01 & 2.77 & 0.06 \\
& Error & 111.91 & 31 & 3.61 & & 0.77 \\
TNF- $\alpha$ & Contrast & 6.80 & 3 & 2.27 & 0.38 & \\
& Error & 186.77 & 31 & 6.03 & & 0.96 \\
IL-6 & Contrast & 1.23 & 3 & 0.41 & 0.11 & \\
& Error & 118.75 & 31 & 3.83 & & 0.88 \\
Leptin & Contrast & 4.45 & 3 & 1.48 & 0.22 & \\
& Error & 212.54 & 31 & 6.86 & & 0.01 \\
TG & Contrast & 43991.56 & 3 & 14663.85 & 4.44 & \\
& Error & 102442.90 & 31 & 3304.61 & & \multirow{2}{*}{0.09} \\
HDL-C & Contrast & 325.37 & 3 & 108.46 & 2.41 & \\
& Error & 1394.74 & 31 & 44.99 & & \\
\hline
\end{tabular}

\footnotetext{
${ }^{1)}$ Sum of square.

${ }^{2)}$ Degree of freedom.

${ }^{3)}$ Mean square

${ }^{4)} \mathrm{F}$ value.

${ }^{5)} \mathrm{P}$ value.
} 
(Table 2).

비만 및 심혈관질환과 관련성이 있는 혈중 TNF-a (Table 4), IL-6 (Table 5) 및 leptin (Table 6) 함량을 측정하였다. TNF$\mathrm{a}$ 는 녹차섭취, 운동 및 이들의 병행처리에 의해 감소되었지만, 운동에 의해서만 유의성 있게 감소하였다 $(p<0.05)$. IL-6의 함 량은 운동처리 및 녹차와 운동 병행처리에서 각각 $p<0.01$ 및 $p \times 0.05$ 수준에서 유의성 있게 감소하였고, 녹차처리에 의해서 는 감소되었지만 유의성은 없었다. 또한 leptin의 함량은 녹차 처리 $(p<0.05)$, 운동처리 $(p<0.05)$ 및 녹차와 운동처리 $(p<0.05)$ 에 의해 유의성 있게 감소하였다. TNF-a, IL-6 및 leptin 함량에 대한 처리간의 효과를 분석한 결과 처리간 차이는 없었다 (Table 2).

Table 7은 TG의 변화를 나타낸 결과이다. TG는 녹차섭취에 의해 유의하게 증가하였으며 $(p<0.01)$, 이는 정상범위 인 143 $\mathrm{mg} / \mathrm{dl}$ 을 초과하였다. 그러나 $\mathrm{TG}$ 의 함량은 운동에 의해서는 증가하였고, 녹차와 운동을 병행처리 한 경우에는 감소하였으 나 유의성은 없었다. 더구나 대조군에서도 유의성은 없지만 증가하였다. 공변인의 효과를 조절하여 분석한 결과 처리간 차이가 나타났으며(Table 2), Bonferroni 검증 결과 녹차처리 는 다른 다른 처리와 비교하여 $p<0.01$ 수준에서 유의성이 있었

Table 5. Change in IL-6 concentration in bloods from subjects treated with green tea extract and exercise for 12 weeks

\begin{tabular}{llll}
\hline \multirow{2}{*}{ Group $^{1)}$} & \multicolumn{2}{c}{ IL-6 $(\mathrm{pg} / \mathrm{dl})$} & \multirow{2}{*}{$\begin{array}{c}\text { Paired } \\
\text { t-test }\end{array}$} \\
\cline { 2 - 3 } & $\begin{array}{c}\text { Prior to } \\
\text { treatment }\end{array}$ & $\begin{array}{c}\text { Post } \\
\text { treatment }\end{array}$ & \\
\hline Control & $3.93 \pm 4.51^{2)}$ & $3.09 \pm 3.97$ & 0.50 \\
Green Tea & $0.97 \pm 0.56$ & $0.66 \pm 0.56$ & 1.68 \\
Exercise & $2.01 \pm 0.64$ & $0.76 \pm 10.65$ & $4.02^{* *}$ \\
Green Tea \& Exercise & $2.14 \pm 3.43$ & $0.74 \pm 0.81$ & $2.44^{*}$ \\
\hline
\end{tabular}

${ }^{1)}$ Green tea extract (1.5-1.7 g dry weight/ $120 \mathrm{ml}$ tap water, $\left.90^{\circ} \mathrm{C}\right)$ was daily given to a subject for 12 weeks. Strength and duration of exercise were shown in Materials and Methods.

${ }^{2)} \mathrm{Mean} \pm \mathrm{SD}$ of 9 individuals.

${ }^{*} p<0.05$, and ${ }^{* *} p<0.01$.

Table 6. Change in leptin concentration in bloods from subjects treated with green tea extract and exercise for 12 weeks

\begin{tabular}{lccc}
\hline \multirow{2}{*}{ Group ${ }^{1)}$} & \multicolumn{2}{c}{ Leptin $(\mathrm{pg} / \mathrm{dl})$} & \multirow{2}{*}{$\begin{array}{c}\text { Paired } \\
\text { t-test }\end{array}$} \\
\cline { 2 - 3 } & $\begin{array}{c}\text { Prior to } \\
\text { treatment }\end{array}$ & $\begin{array}{c}\text { Post } \\
\text { treatment }\end{array}$ & \\
\hline Control & $6.26 \pm 6.41^{2)}$ & $5.10 \pm 3.48$ & 0.91 \\
Green Tea & $11.58 \pm 7.21$ & $6.43 \pm 3.00$ & $2.50^{*}$ \\
Exercise & $6.96 \pm 3.67$ & $4.53 \pm 4.08$ & $3.21^{*}$ \\
Green Tea \& Exercise & $13.41 \pm 8.26$ & $7.65 \pm 3.90$ & $2.97^{*}$ \\
\hline
\end{tabular}

${ }^{1)}$ Green tea extract (1.5-1.7 g dry weight/120 ml tap water, $\left.90^{\circ} \mathrm{C}\right)$ was daily given to a subject for 12 weeks. Strength and duration of exercise were shown in Materials and Methods.

${ }^{2)} \mathrm{Mean} \pm \mathrm{SD}$ of 9 individuals.

${ }^{*} p<0.05$.
다(Table 7). 이와 같은 결과는 녹차섭취나 운동에 의해 TG의 함량이 감소한다는 보고와 상이한 결과이다[12,15,17].

녹차섭취와 운동은 혈중 HDL-C 함량에는 영향을 미치지 않았고, 오히려 녹차섭취와 운동을 병행하였을 경우 HDL-C 의 농도가 유의적 $(p<0.05)$ 으로 낮아졌다(Table 8). 이와 같은 결과는 기존의 결과와는 상반되는 결과이다[11,17]. HDL-C는 $\mathrm{TG}$ 치 변화에 영향을 받게 되는데 녹차섭취와 운동에 의해 TG 의 증가가 HDL-C 감소에 영향을 미친 것으로 본다. 또한 본 연구에 참여한 대상의 기저치 TG와 HDL-C 수치가 정상범위 내이기 때문에 처리의 긍정적인 변화를 유도하지 못한 것으로 생각된다. 특히 녹차섭취군의 정상 TG수치에서 12 주 후 임상 적으로 높은 수치가 나타난 점은 실험기간 중 식이 관리가 제대로 되지 못하였기에 나타난 결과라고 본다. 즉 녹차섭취 에 따른 TG 증가는 실험 처치기간 내 고지방섭취에 의한 변화 일 것으로 생각된다.

비만은 염증유발 상태에 의해 심혈관질환의 주된 원인으로 간주되고 있다[21]. 이는 비만 지방조직에서 분비되는 염증성 사이토카인 인 TNF- $a$ 와 IL- 6 의 분비 증가가 죽상동맥경화증 을 진행시키기 때문인 것으로 보고되고 있다[18,21,22]. 염증반

Table 7. Change in TG concentration in bloods from subjects treated with green tea extract and exercise for 12 weeks

\begin{tabular}{|c|c|c|c|}
\hline \multirow[b]{2}{*}{ Group $^{1)}$} & \multicolumn{2}{|c|}{ TG (mg/dl) } & \multirow[b]{2}{*}{$\begin{array}{c}\text { Paired } \\
\text { t-test }\end{array}$} \\
\hline & $\begin{array}{l}\text { Prior to } \\
\text { treatment }\end{array}$ & $\begin{array}{c}\text { Post } \\
\text { treatment }\end{array}$ & \\
\hline Control & $70.56 \pm 13.13^{2)}$ & $103.89 \pm 76.48^{\mathrm{a} 3)}$ & -1.47 \\
\hline Green Tea & $108.44 \pm 62.62$ & $187.56 \pm 95.01^{\mathrm{b}}$ & $-4.15^{* *}$ \\
\hline Exercise & $79.22 \pm 44.27$ & $94.00 \pm 47.59^{\mathrm{a}}$ & -1.29 \\
\hline Green Tea \& Exercise & $131.33 \pm 96.20$ & $112.33 \pm 96.98^{\mathrm{a}}$ & 0.93 \\
\hline
\end{tabular}

${ }^{1)}$ Green tea extract (1.5-1.7 g dry weight/120 ml tap water, $90^{\circ} \mathrm{C}$ ) was daily given to a subject for 12 weeks. Strength and duration of exercise were shown in Materials and Methods.

${ }^{2)}$ Mean \pm SD of 9 individuals.

${ }^{3)}$ Different superscripts in the same column differ significantly at $5 \%$ level by Bonferroni test. ${ }^{* *} p<0.01$.

Table 8. Change of HDL-C concentration in bloods from subjects treated with green tea extract and exercise for 12 weeks

\begin{tabular}{lccc}
\hline \multirow{2}{*}{ Group ${ }^{1)}$} & \multicolumn{2}{c}{ HDL-C $(\mathrm{mg} / \mathrm{dl})$} & Paired \\
\cline { 2 - 3 } & $\begin{array}{c}\text { Prior to } \\
\text { treatment }\end{array}$ & $\begin{array}{c}\text { Post } \\
\text { treatment }\end{array}$ & t-test \\
\hline Control & $\left.47.50 \pm 5.80^{2}\right)$ & $46.26 \pm 8.29$ & 0.70 \\
Green Tea & $46.83 \pm 6.91$ & $47.31 \pm 6.53$ & -0.23 \\
Exercise & $55.49 \pm 7.46$ & $56.52 \pm 8.10$ & -0.29 \\
Green Tea \& Exercise & $48.92 \pm 5.76$ & $44.34 \pm 6.22$ & $2.34^{*}$ \\
\hline
\end{tabular}

${ }^{1)}$ Green tea extract $\left(1.5-1.7 \mathrm{~g}\right.$ dry weight $/ 120 \mathrm{ml}$ tap water, $90^{\circ} \mathrm{C}$ ) was daily given to a subject for 12 weeks. Strength and duration of exercise were shown in Materials and Methods.

${ }^{2)}$ Mean \pm SD of 9 individuals. " $p<0.05$. 
응은 TNF- $a$ 와 IL-6는 leptin 분비를 촉진시키는 것으로 알려져 있다. Leptin은 지방세포에서 지방축적에 의하여 분비되며 식 욕억제 및 에너지소비를 증가시키지만 비만환자의 leptin 농 도는 높아져 있으므로 leptin 투여에도 반응하지 않는 leptin 저항성이 발생된다고 밝혀지고 있다[3]. 운동은 염증반응을 억 제하여 세포자멸을 유도하는 TNF- $a$ 농도 감소와 관련이 있는 데[21], 비만 흰쥐 및 비만 환자에게 운동으로 체중감소를 유도 할 경우 혈중 TNF-a 수준이 감소되는 것으로 알려져 있다 $[8,11,16,18]$. 또한 운동은 비만에 의해 높아진 leptin 수준을 낮추는 것으로 보고되고 있다 $[12,25,26]$. 본 연구에서, 녹차섭 취는 leptin의 농도만 감소시켰고( $p<0.05)$, 운동은 TNF- $a$ $(p<0.05), \mathrm{IL}-6 \quad(p<0.01)$ 및 leptin 농도 $(p<0.05)$ 를 감소시켰다. 녹차섭취와 운동 병행은 IL-6 ( $p<0.05)$ 과 leptin 농도( $p<0.05)$ 를 감소시켰다. 이와 같이 녹차섭취에 의한 leptin 감소 및 녹차섭 취와 운동병행으로 IL-6과 leptin이 감소된 점은 비만의 관상 동맥질환 병변에서 염증유발 억제 및 에너지균형 조절에 긍정 적인 영향을 미칠 수 있을 것으로 기대된다.

그러나 TNF- $a$ 와 IL- 6 은 지방조직의 TG 분해를 자극하지만 본 연구에서 녹차 섭취에 의해 TG가 증가함(Table 7)에도 불구 하고 IL-6과 leptin이 감소된 점은 녹차섭취에 의한 효과라고 판단하기 어렵다. 즉 처리군과 대조군의 실험기간 중 $\mathrm{TG}$ 에 영향을 미칠 수 있는 식생활에 대한 관리를 하였으나 보고되 지 않은 식생활 습관이 TG에 영향을 미칠 수가 있을 것으로 생각된다. 한편으로 연구대상자의 연령이 발육과 발달이 왕성 한 시기로서 녹차섭취의 효과를 초과하여 일시적 또는 자연적 혈중 일부 요인의 변화가 있을 것으로 생각된다.

결론적으로 비만 중학생을 대상으로 한 녹차섭취 및 운동의 비만세포에서 분비되는 cytokine인 TNF-a, IL-6 및 leptin의 함량에 미치는 영향은 녹차섭취 및 운동의 효과는 볼 수 있었 다. 그러나 이들의 시너지 효과는 볼 수 없었다. 이런 결과는 아마도 실험대상이 활동이 가장 활발한 중학생이었기 때문일 것으로 사료된다.

\section{감사의 글}

본 논문은 하동녹차연구소의 지원에 의하여 이루어진 결과 의 일부입니다.

\section{References}

1. Arita, Y., S. Kilhara, N. Ouchi, M. Tkahashim, K. Maeda, J. Miyagawa, K. Hotta, I. Shimomura, T. Nakamura, K. Miyaoka, H. Kuriyama, M. Nishida, S. Yamashita, K. Okubo, K. Matsubara, M. Muraguchi, Y. Ohmoto, T. Funahshi, and Y. Matusbara. 1999. Paradoxical decrease of an adipo-specific protein adiponectin in obesity. Biochem Biophys. Res. Commun. 257, 79-83.
2. Choi, M. J. and S. H. Kim. 2010. Effects of green tea powder supplementation on blood glucose and lipid concentration in rats with streptozotocin-induced diabetes. $J$. East Asian Soc. Dietary Life 20, 46-53.

3. Fasshauer, M., J. Klein, S. Neumann, M. Eszlinger, and R. Pashke. 2002. Hormonal regulation of adiponectin, gene expression in 3T3-L1 adipocytes. Biochem Biophys. Res. Commun. 290, 1084-1089.

4. Hill, A. M., A. M. Coates, J. D. Buckley, R. Ross, F. Thielecke, and P. R. Howe. 2007. Can EGCG reduce abdominal fat in obese subjects? J. Amer. College Nutri. 26, 396S-402S.

5. Imai, K. and K. Nakachi. 1995. Cross sectional study of effects of drinking green tea on cardiovascular and liver disease. BMJ 310, 693-696.

6. Jang, H. D. 2004. Regulation of NF-/B transcriptional activity by PIAS3 and TRAF6. Ph.D. Thesis, Ewha Womans University, Seoul, Republic of Korea.

7. Jo, H. S. 2006. Effects of combined exercise and green tea intake on body composition, blood lipid profile, insulin and adiponectin in abdominal obese high school female students. Ph. D. Thesis, Pusan National University, Pusan, Republic of Korea.

8. Jung, S. H., H. S. Park, K. S. Kim, W. H. Choi, C. W. Ahn, B. T. Kim, S. M. Kim, S. Y. Lee, S. M. Ahn, Y. K. Kim, H. J. Kim, D. J. Kim, and K. W. Lee. 2007. Effect of weight loss on some serum cytokines in human obesity: increase in IL-10 after Weight loss. J. Nutr. Biochem 3, 98-102.

9. Karvoven, M. J., E. Kentala, and O. Mustala. 1957. The effects of training of heart rate: a longitudinal study. Ann. Med Exp. Biol. Fenn. 35, 307-315.

10. Kim, D. C. 2007. The effect of green tea polyphenol on cisplatin-induced cytotoxicity in human uterine cervix cancer cell lines. Ph. D. Thesis, Chosun University, Gwangju, Republic of Korea.

11. Kondo, T., K. Isao, and M. Murakami. 2005. Effect of exercise on circulating adipokine levels in obese young women. Endocr. 53, 189-195.

12. Kraus, W. E., J. A. Houmard, B. D. Duscha, K. J. Knetzger, M. B. Wharton, J. S. McCaryney, C. W. Bales, S. Henes, G. P. Samsa, J. D. Otvos, K. R. Kulkarni, and C. A. Slentz. 2002. Effects of amount and intensity of exercise on plasma lipoproteins. N. Engl. J. Med 347, 1483-1492.

13. Kwon, Y. C., M. S. Youn, and S. K. Park. 2003. The effect of combined training on lymphocyte and TNF-a concentration in obese adolescent. Korean J. Phys. Edu. 42, 335-345.

14. Lamarche, B., J. P. Despres, M. C. Pouliot, S. Moorjani, P. J. Lupien, G. Theriault, A. Tremblay, A. Nadeau, and C. Bouchard. 1992. Is body fat loss a determinant factor in the improvement of carbohydrate and lipid metabolism following aerobic exercise training in obese wom- 
an?. Metabolism 41, 1249-1256.

15. Motoyama, M., Y. Sunami, F. Kinoshita, T. Irie, J. Sasaki, K. Arakawa, A. Kiyonaga, H. Tanaka, and M. Shindo. 1995. The effects of long term low intensity aerobic training and detraining on serum lipid and lipoprotein concentration in elderly men and women. Eur. J. Appl. Physiol. 70, 126-131.

16. Park, S. K., E. H. Kim, and Y. C. Kwon. 2008. Effects of combined exercise on cardiac structure and function and adipocytokine concentrations in abdominal visceral obese men. J. Korean Sports Med 26, 63-70.

17. Raederstorff, D. G., M. F. Schlachter, V. Elste, and P. Weber. 2003. Effect of EGCG on lipid absorption and plasma lipid levels in rats. J. Nutr. Biochem 14, 326-333.

18. Samartin, S. and R. K. Chandra. 2001. Obesity, over nutrition and the immune system. Nut. Res. 21, 243-262.

19. Seo, H. L. 2004. The effects of exercise and green tea extracts on the body weight, blood glucose, insulin, serum lipid and antioxidants activation in STZ-induced diabetes rat. Ph.D. Thesis, Pusan National University, Pusan, Republic of Korea.

20. Sharma, A. M. 2002. Adipose tissue: a mediator of cardiovascular risk. Int. J. obesity Rel. Met. Disorders 26, S5-S7.

21. Sloan, R. P., P. A. Shapino, R. E. D. Meersman, P. S. Mckinley, K. J. Tracey, I. Slavov, Y. Fang, and P. D. Flood. 2007. Aerobic exercise attenuates inducible TNF production in human. J. Appl. Physiol. 12, 65-72.

22. Valle, M., F. Gascon, R. Martos, F. J. Ruz, F. Bermudo, R. Morales, and R. Canete. 2002. Metabolic cardiovascular syndrome in obese prepubertal children: the role of high fasting insulin levels. Metabolism 51, 423-428.

23. Watanade, J., J. Kawabata, and R. Niki. 1998. Isolation and identification of acetyl-CoA carboxylase inhibitors from green tea (Camellia sinensis). Biosci. Biotechnol. Biochem 62, 532-534.

24. Yang, F., W. J. S. de Villiers, C. J. McClain, and G. W. Varilek. 1998. Green tea polyphenols block endotoxin-induced tumor necrosis factor-production and lethality in a murine model. J. Nutr. 128, 2334-2340.

25. Zheng, D., M. H. Wooter, Q. Zhou, and G. L. Dohm. 1996. The effect of exercise on obgene expression. Biochem Biophys. Res. Commun. 225, 747-750.

26. Ziccardi, P., F. Nappo, G. Giugliang, K. Esposito, R. Marfella, M. Cioffi, F. D'Andrea, A. M. Molinari, and D. Giugliano. 2002. Reduction of inflammatory cytokine concentrations and improvement of endothelial functions in obese women after weight loss over one year. Circulation 19, 804-809.

27. Venables, M. C., C. J. Hulston, H. R. Cox, and A. E. Jeukendrup. 2008. Green tea extract ingestion, fat oxidation, and glucose tolerance in healthy humans. Am J. Clin Nutr. $87,778-784$.

\title{
초록 : 녹차섭취와 운동에 의한 비만 청소년의 혈중 biochemical marker 함량 감소
}

\author{
양재경 ${ }^{1} \cdot$ 정지영 ${ }^{1} \cdot$ 강설중 $^{2} \cdot$ 정강원 $^{3} \cdot$ 김종철 ${ }^{4} \cdot$ 고성경 ${ }^{5} \cdot{\text { 정소봉 }{ }^{2}}^{*}$ \\ ( ${ }^{1}$ 경상대학교 환경산림과학부, 농업 생명과학연구원, ${ }^{2}$ 경상대학교 체육교육과, ${ }^{3}$ 경상대학교 생명과학부, ${ }^{4}$ 하 \\ 동 녹차연구소, ${ }^{5}$ 대구대학교 체육학과)
}

녹차섭취와 유산소운동이 비만 남자중학생의 체중과 혈중 biochemical marker에 미치는 영향에 관하여 연구 하였다. 체지방율이 $25 \%$ 이상인 비만 남자중학생 36 명을 대상으로 대조군 $(n=9)$, 녹차처리군 $(n=9)$, 운동군 $(n=9)$ 과 녹차와 운동 병행군 $(\mathrm{n}=9)$ 으로 분류하여, 운동은 주 5 회 60 분씩 12 주간 실시하였고, 녹차는 녹차열수출물을 음용 (녹차건중 1.5-1.7 g/일) 하였다. 대조군은 녹차처리군이 섭취한 양의 물을 섭취하였다. 실험 시작전과 12주 후의 혈중 TNF-a, IL-6, leptin, TG 및 HDL-C 함량을 측정하였다. 대조군을 포함한 모든 처리군에서 체중 변화는 없었 으나 병행군은 복부지방률이 감소하였다. 대조처리는 TNF-a, IL-6 및 leptin 함량에 아무런 영향을 미치지 않았 다. 녹차처리는 leptin $(p<0.05)$ 을 감소시켰고, TG $(p<0.01)$ 는 증가시켰다. 운동은 TNF-a $(p<0.05), \mathrm{IL}-6(p<0.01)$ 및 leptin $(p<0.05)$ 함량을 감소시켰다. 또한 녹차처리와 운동 병행은 IL-6 $(p<0.05)$, leptin $(p<0.05)$ 및 HDL-C $(p<0.01)$ 함량을 감소시켰다. 이 결과는 녹차섭취나 운동은 젊은 비만 중학생의 혈중 염증 cytokine인 TNF-a, IL-6 및 leptin 함량 감소에 효과가 있었으나, 녹차섭취와 운동의 병행에 의한 synergy 효과는 없었다. 